\title{
Валентина Марченко
}

кандидат філологічних наук, доцент

Національний технічний університет України

«Київський політехнічний інститут імені Ігоря Сікорського»

Київ, Україна

ORCID ID 0000-0002-9291-471X

seonolut@gmail.com

\section{Олена Матюшенко}

студентка 2 курсу магістратури факультету лінгвістики

Національний технічний університет України

«Київський політехнічний інститут імені Ігоря Сікорського»

Київ, Україна

alenamatyshenko03@gmail.com

\section{СПОСОБИ ВІДТВОРЕННЯ АНГЛОМОВНИХ ВИСЛОВЛЮВАНЬ 3 ОЗНАКАМИ МОВИ ВОРОЖНЕЧІ УКРАЇНСЬКОЮ МОВОЮ}

\begin{abstract}
Стаття присвячена вивченню особливостей перекладу висловлювань з ознаками мови ворожнечі засобами української мови. Серед методів дослідження чільне місце посідає структурний метод, завдяки якому було розглянуто мову ворожнечі як систему, з характерними їй компонентами: вербальними та невербальними засобами й формами реалізації у мові. Використання зіставного методу дозволило встановити подібності, відмінності та специфіку англомовних засобів вираження мови ворожнечі через системне порівняння з українською мовою. Домінуючим методом представленого дослідження є кількісний аналіз текстів оригіналу й перекладу, який було використано для визначення найчастотніших способів відтворення засобів мови ворожнечі при перекладі. Особлива увага приділяється виявленню найчастотніших способів перекладу мови ворожнечі, що уможливлюють збереження іiі лінгвопрагматичних та соціокультурних особливостей. Розглянуто також лінгвопрагматичний та соціокультурні аспекти. У статті представлено результати кількісного аналізу використання перекладацьких трансформацій при відтворенні мови ворожнечі для іноземної лінгвокультури. У представленому дослідженні було продемонстровано результати кількісного аналізу, що базується на майже 400 англомовних висловлюваннях, які було зафіксовано у різних сферах використання та у різних формах прояву. Найяскравіші приклади було детально проаналізовано, обгрунтовуючи той чи інший вибір способу перекладу. Аналіз перекладу було представлено за такою структурою: мова ворожнечі у сучасних соціальних мережах; прояви мови ворожнечі, зафіксовані у сучасних рекламних кампаніях та вінтажній рекламі; прояви мови ворожнечі, викликані COVID-19; мова ворожнечі, зафіксована у телешоу, серіалах та кіно; прояви мови ворожнечі у Інтернет-мемах. Феномен «мови ворожнечі» розглядається також як актуальне міждисциплінарне явище, яке потребує грунтовних науковолінгвістичних розвідок, для запобігання його небезпечним наслідкам.
\end{abstract}

Ключові слова: мова ворожнечі; риторика ненависті; мова ворожнечі; вербальні та невербальні засоби мови ворожнечі; перекладацький аспект; соціокультурний аспект.

\section{1. ВСТУП}

Постановка проблеми. Мова як жива система, що функціонує і розвивається разом із суспільством, іноді, на жаль, реагує й на негативні події та явища у світі. Таким чином на сьогоднішній день у світі спостерігається апогей розвитку феномену мови ворожнечі, що поширюється зі швидкістю світла, набуваючи нових небезпечних форм вираження. Саме тому до цього явища зараз прикута увага дослідників із різних галузей: соціологів, психологів, політологів, журналістів, а також лінгвістів.

(C) Valentyna Marchenko, Olena Matiushenko. 2022. Published by Igor Sikorsky Kyiv Polytechnic Institute. This is an Open Access article distributed under the terms of the licence CC BY 4.0 
Оскільки феномен мови ворожнечі залишається досі малодослідженим лінгвістичним феноменом, особливої уваги потребують наукові розробки в перекладацькому аспекті. На нашу думку, при відтворенні англомовних висловлювань з ознаками риторики ненависті, перекладач може зіткнутися 3 певними складнощами, зокрема вибором доречних перекладацьких трансформацій, що дозволяють досягти еквівалентності перекладу й збереження оригінального емоційного забарвлення вихідної мови, а також віднайти у мові перекладу ті лексичні одиниці, що мали б ту саму конотацію для цільової лінгвокультури. Саме тому у цьому досліджені ми пропонуємо розглянути особливості перекладу мовних та позамовних засобів реалізації hate speеch українською мовою.

Аналіз останніх досліджень та публікацій. Незважаючи на те, що мова ворожнечі вважається малодослідженим лінгвістичним феноменом, проаналізувавши попередні наукові розробки вітчизняних та зарубіжних авторів, можемо з упевненістю зазначити, що вивчення цього явища $є$ багатоаспектним, багатогранним та перспективним. Цій темі присвячена велика кількість статей та наукових досліджень, що розглядають мову ворожнечі у різних аспектах. Так, наприклад, серед у вітчизняній лінгвістиці вивченням мови ненависті займаються такі мовознавці як-от: Черненко, Сарміна, Ісакова, Богданова та Лепуга. Серед зарубіжних наукових розробок у дискурсі hate speech особливої уваги заслуговують дослідження таких мовознавців: Клейн, Бахадор, Волкер, Бенеш, Бюргер, Главініч, Маніон, Батейко та Ноблок.

Метою дослідження $є$ виявлення найчастотніших способів перекладу мови ворожнечі англомовного лінгвокультурного простору засобами української мови, що уможливлюють збереження їі лінгвопрагматичних та соціокультурних особливостей.

\section{2. МЕТОДИ}

Серед методів дослідження чільне місце посідає структурний метод, завдяки якому було розглянуто мову ворожнечі як систему, з характерними їй компонентами: вербальними та невербальними засобами й формами реалізації у мові. Використання зіставного методу дозволило встановити подібності, відмінності та специфіку англомовних засобів вираження мови ворожнечі через системне порівняння з українською мовою. Домінуючим методом представленого дослідження є кількісний аналіз текстів оригіналу й перекладу, який було використано для визначення найчастотніших способів відтворення засобів мови ворожнечі при перекладі.

\section{3. РЕЗУЛЬТАТИ ТА ОБГОВОРЕННЯ}

\section{1. Перекладацькі трансформації у дискурсі мови ворожнечі}

Специфіка перекладу мови ворожнечі є малодослідженим аспектом. Саме тому у нашому дослідженні ми приділили особливу увагу аналізу прийомів та тактик відтворення «hate speech» українською мовою. У нас $є$ гіпотеза, що при перекладі висловлювань 3 ознаками ненависті та нетерпимості, перекладачі зіштовхуються 3 великою кількістю «підводного каміння». Адже мова ворожнечі (як i, наприклад, явище ненормативної лексики) має специфічні лінгвокультурні та соціальні особливості.

3 метою перевірки цієї гіпотези, далі пропонуємо розглянути детально приклади прояву мови ворожнечі в англійській лінгвокультурі, враховуючи стратегії та тактики реалізації риторики ненависті, а також аналізуючи перекладацькі трансформації, які були використані при відтворенні їх українською мовою.

Досягнення адекватності перекладу, незважаючи на розбіжності у формальних та семантичних системах двох мов, вимагає від перекладача використання перекладацьких трансформацій. У нашому досліджені для здійснення комплексного аналізу відтворення англомовних проявів мови ворожнечі українською мовою ми будемо спиратися на узагальнену класифікацію перекладацьких перетворень, яка базується на основі теоретичних розробок таких мовознавців як-от Бархударов (2014), Коміссаров (2001), а також на основі підходу до класифікації трансформацій, представлених у підручнику «Основи перекладу - 
міст між теорією і практикою (німецько-український напрям)» (Lysenko, Baklan, \& Chepurna, 2019). Так, узагальнена нами класифікація виглядає наступним чином: 1) граматичні трансформації (об'єднання та членування речень, додавання, вилучення, перестановка, заміна, комплексна трансформація, дослівний переклад); 2) лексичні (вибір варіантного відповідника, транскодування, калькування, конкретизація, генералізація, диференціація значення, модуляція, антонімічний переклад, експлікація, цілісне перетворення, компенсація, експресивізація, нейтралізація та перекладацький коментар).

На нашу думку, вищенаведена узагальнена класифікація перекладацьких тактик $є$ найповнішою та найвичерпнішою у дискурсі нашого дослідження, що уможливлює комплексний аналіз способів відтворення висловлювань ненависті українською мовою.

У рамках нашого дослідження ми проаналізували майже 400 англомовних висловлювань, які ми зафіксували у різних сферах використання та у різних формах прояву. Таким чином надалі аналіз буде представлений за такою структурою: мова ворожнечі у сучасних соціальних мережах; прояви мови ворожнечі, зафіксовані у сучасних рекламних кампаніях та вінтажній рекламі; прояви мови ворожнечі, викликані COVID-19; мова ворожнечі, зафіксована у телешоу, серіалах та кіно; прояви мови ворожнечі у Інтернет-мемах. У цій роботі ми пропонуємо детально розглянути найяскравіші приклади з проаналізованого нами перекладу висловлювань, з ознаками hate speech.

\section{2. Мова ворожнечі у сучасних соціальних мережах}

Як відомо, соціальні мережі призначені для вільного вираження власної думки, а й отже, на жаль, вони $є$ основною платформою для реалізації та поширення мови ворожнечі. Нами було проаналізовано 200 ворожих висловлювань з сучасних популярних мереж (зокрема, Twitter, Facebook, Instagram, Reddit), тому в продемонстрованих приклади може бути наявна нецензурна лексика. Найрекурентнішою трансформацією є вибір варіантного відповідника, яка часто зустрічається з нейтралізацією та протилежною їй експресивізацією: "Ignorant feminist" (Mollas, Chrysopoulou, Karlos \& Tsoumakas, 2021). - Неосвічена реміністка. If I were your dad, I'd Google "Abortions at 30 years old mentally handicapped" (Mollas, Chrysopoulou, Karlos, \& Tsoumakas, 2021). - «Будь я твоїм батьком, я б загуглив «аборти в 30-річних розумово відсталих». "Why don't you go beck your god to murder you?" Christianity is a joke (Mollas, Chrysopoulou, Karlos, \& Tsoumakas, 2021). - «Чому б тобі не дати знак своєму богу вбити тебе? Християнство ие посміховисько».

Дослівний переклад найчастіше зустрічається як єдина техніка. Також частотним $\epsilon$ його поєднання 3 трансформацією додавання (як для підсилення/передачі оригінального емоційно-забарвленого настрою, так і для конкретизаціï): "People with [Disease] are rats that contaminate everyone around them" (Mollas, Chrysopoulou, Karlos, \& Tsoumakas, 2021).«Люди з [хворобою] - щури, що заражають всіх навколо себе». "We mеn enjoy the reproductive rights of paying for your abortion” (Mollas, Chrysopoulou, Karlos, \& Tsoumakas, 2021). - "Ми, чоловіки, насолоджуємося репродуктивними правами на оплату вамого аборту». "We whites have higher IQ's than blacks" (Mollas, Chrysopoulou, Karlos, \& Tsoumakas, 2021). - «У нас, білих, вище IQ, ніж у чорних людей». "Why does Bulgaria exist as a country? It's one of those homosexual ones" (Mollas, Chrysopoulou, Karlos, \& Tsoumakas, 2021). - "Чому Болгарія існує як окрема краӥна? Це одна з тих гомосексуальних».

Диференціація значення нерідко використовується при перекладі слів, яким у мові перекладу відповідає низка лексем на основі загальної архісеми. Частим $\epsilon$ поєднання диференціації значення 3 експресивізацією, або нейтралізацісю, що залежить від оригінального емоційного забарвлення вихідної мови. "You should know women's sports are a joke” (Mollas, Chrysopoulou, Karlos, \& Tsoumakas, 2021). - "Ти маєш знати, що жіночий cnopm - ие клоунада" (диференціація значення + експресивізація). “ANTIZIONISTS FOCUS ON KILLING [race] DON'T FUCK AROUND” (Facebook). - "AHTИCIOHICTИ, ЗОСЕРЕДЬТЕСЯ НА ВИНИЩЕННІ [начія], НЕ ВДАВАЙТЕ ДУРНІВ» (Диференціація значення + Нейтралізація). 
У прикладах нижче продемонстровано, як перекладач вдало комбінує одразу декілька перекладацьких трансформацій, для досягнення еквівалентного перекладу, адаптуючи при цьому зміст повідомлення під цільову лінгвокультуру. В нижчеподаному прикладі зафіксовано такі трансформації, як вилучення, вибір варіантного відповідника, додавання, смисловий розвиток (модуляція), членування речення та антонімічний переклад: “This is so sinful. It says it in the bible you dumb fucktards. Stop saying YOU WILL GO TO HEAVEN IF YOU ARE GAY, because you will not go to heaven" (Mollas, Chrysopoulou, Karlos, \& Tsoumakas, 2021). - «Це так грішно. Про ие говориться в біблії, тупі довбо**би. Перестаньте казати, щио ВИ ПОТРАПИТЕ ДО РАЮ, ЯКЩО ВИ ГЕЇ. Бо ви потрапите пекло!».

Калькування, що складає $\mathbf{1 , 3 \%}$, при перекладі риторики ненависті, наявної у соціальних мережах, здебільшого використовується для відтворення назв хвороб, людських фізичних вад та специфічних словосполучень: "People with [Disability] are subhuman and shouldn't be seen in public" (Mollas, Chrysopoulou, Karlos, \& Tsoumakas, 2021). - «Люди 3 [інвалідністю] - недолюди, і їм не слід показуватися на очі». "Incest baby that got doubledown syndrome" (Mollas, Chrysopoulou, Karlos, \& Tsoumakas, 2021). - "Дитя інцесту 3 подвійним діагнозом синдрому Дауна».

“@usr shut the $f^{*}$ ck up you stupid $n *$ gger I honestly hope you get brain cancer” (Twitter). «@користувач заткнись на**й дебілоїдний нігzер. Я щиро сподіваюся, у тебе знайдуть_рак мозку».

“@usr A sh*ts*cking Muslim bigot like you wouldn't recognize history if it crawled up your $c^{*}$ nt. You think photoshop is a truth machin” (Twitter). - «@користувач Такий фанатичний гівножер-мусульманин як ти не визнає історію, навіть якщо вона влізе тобі в $n^{* *} у$. Думаєш, фотошоп - машина правди?».

До транскодування перекладачі вдавалися здебільшого для передачі особистих імен, назв загальновідомих трагічних подій, назви хвороб, позначення раси та сленгу: “R.I.P Adolf Hitler (Suicide memorial page). Let's all take a second to remember Hitler. He killed himself, which makes everything he's ever done irrelevant and he should not have to take responsibility for his actions" (Oboler, 2013, p. 45). - "Спочивай з миром, Адольф Гітлер (Сторінка пам'яті самогубства). Знайдемо секунду, щоб згадати Гітлера. Він учинив самогубство, щзо робить усі його діяння неважливими, і він не повинен нести відповідальність за свої дії».

"The Holocaust was the greates thing that ever happened"(Oboler, 2013, p. 45).«Холокост - найкраще серед усього, що траплялося».

"LOL HE'S A JEW RITE?" (Oboler, 2013, p. 50).-« ПРАВИЛЬНО?».

"Throwing stones to paraplegic kids is my favourite hobby" (Mollas, Chrysopoulou, Karlos, \& Tsoumakas, 2021). - "Кидати камінням у дітей, хворих на_параплегію, моє улюблене заняття».

“@usr shut the f*ck up you stupid n*gger I honestly hope you get brain cancer” (Twitter). @користувач заткнись на**й дебілоїдний ніггер. Я щиро сподіваюся, у тебе знайдуть_рак мозку».

\section{3. Мова ворожнечі у сучасних рекламних кампаніях та вінтажній рекламі}

Досліджуючи феномен мови ворожнечі, ми помітили, що це явище існувало здавна i відображало настрої, переконання суспільства та існуючі в ньому негативні стереотипи. Так, ми проаналізували приклади прояву мови ненависті, наявні у вінтажних та сучасних рекламних оголошеннях. Пропонуємо розглянути детальніше на найяскравіших прикладах, чим саме зумовлений той чи інший вибір перекладацької трансформації.

Розглянемо, у яких випадках перекладачі вдавалися до дослівного перекладу: "So, the harder a wife works, the cuter she looks!” (Brown, Healy, \& Moon, 2018). - «Чим важче прачює жінка, тим миліше вона виглядає!». "We are going to Use Chlorinol and be like de White Nigger” (Brown, Healy, \& Moon, 2018). - «Ми скористаємося хлоркою та будемо як ті білі 
нігzери». “Men are better than women!” (Brown, Healy, \& Moon, 2018). - «Чоловіки кращі за жінок!».

Також частим $\epsilon$ поєднання синтаксичного уподібнення (дослівного перекладу) 3 вибором варіантного відповідника, що також $є$ найбільш використовуваним прийомом: "Cheat on your girlfriend, not on your workout" (Mertes, 2021). - «Зраджуй своїй дівчині, а не тренуванню». "Men Ask «Is She Pretty?» not «Is She Clever?” (Brown, Healy, \& Moon, 2018). «Чоловік питає «Вона красива?», а не «Вона розумна?».

$\mathrm{y}$ наступних прикладах можна помітити, як за допомогою вибору варіантного відповідника та експресивізації у мові перекладу відтворюється мова ворожнечі: "Coolest monkey in the jungle” (Brennan, \& Feldman, 2018). - «Найкрутіша мавпочка у джунглях». "Did you ever see a fat Chinese?” (Brown, Healy, \& Moon, 2018). - «Ви колись бачили жирнющого китайия?».

Комплексна трансформація є однією з пріоритетних при перекладі рекламних текстів, 3 проявами нетерпимості, яка у більшості випадків містила у собі такі трансформації: заміна та перестановка: “Where has daddy gone? Only mother knows...Dropson's Grinders" (Brown, Healy, \& Moon, 2018). - «Куди це подівся татусь? Відомо лише мамі... М'ясорубки Dropson». "Christmas morning she'll be happier with a Hoover" (Brown, Healy, \& Moon, 2018). - «Bpaнui на Різдво вона стане шасливішою завдяки пилососу». "Is it always illegal to kill a woman?" (Brown, Healy, \& Moon, 2018). - «Чи завжди вбивство жінки є злочином?».

Описовий переклад (експлікація) використовується для адекватного передання змісту лексичних компонентів: “...Lucy's rubbing thighs, magically combined with a sticking out jaw and drooping breasts, will turn any trip to the mall into an unforgettable experience... Shop like never before, with your own freckled pile of cellulite!" (Sharp, 2009). - "...Стегна Люсі, що труться одне об одного, чарівно поєднанні з випертою щелепою й обвислими грудьми перетворить будь-яку поїздку в торговий иентр на незабутній досвід. Шоптеся як ніколи раніме зі своєю власною купою челюліту, вкритого веснянками!».

Також частотним $є$ використання конкретизації, яка використовується для заміщення лексеми оригіналу ширшої семантики вужчою (таким чином автор досягає збереження первинного змісту повідомлення): "The Chef does everything but cook - that's what wives are for!” (Brown, Healy, \& Moon, 2018). - «Шеф робить усе, крім приготування їжі - для иього $є$ дружина!» "It's nice to have a girl around the house" (Brown, Healy, \& Moon, 2018). - «ㄹучно мати вдома дівчину».

\section{4. Прояви мови ворожнечі, викликані COVID-19}

Як ми вже раніше зазначалося, мова ворожнечі є лінгвістичним явищем, яке як дзеркало відображає соціальні перетворення та проблеми сьогодення. Яскравим прикладом реалізації вербальної агресії, нетерпимості, дискримінації, страху, паніки та відчуття небезпеки може слугувати актуальна надзвичайна ситуація у світі, викликана пандемією COVID-19. При пошуку матеріалів дослідження, ми помітили яскраво виражену риторику ненависті, пов'язану з темою пандемії. Саме тому ми винесли такі висловлювання в окрему категорію досліджуваної нами «hate speech». Пропонуємо розглянути детальніше на найяскравіших прикладах, чим саме обумовлений вибір такий набір трансформацій.

Традиційно, найуживанішим прийомом перекладу став дослівний переклад, який частіше зустрічається у поєднанні з вибором варіантного відповідника: "China killing millions of people" (Twitter). - «Китай вбиває мільйони людей». "We have no vaccines against morons" (People Can't Stop, 2019). - У нас немає вакцин від кретинів».

Транскодування стало у нагоді при перекладі лексем, до яких важко знайти еквівалентний відповідник, що не спотворив би оригінальне стилістичне забарвлення. Також ця трансформація використовувалася для перекладу слів на позначення раси. "Chink, gook, slant, nip, zipper-head, squint, yellowman, coolie, slope - it's all sooo confusing!..." (LIGHT, 2020). - Китайоза, гук, косоокий, япошка, вузьколобий, жовтопикий - це тааак заплутано!...». "Retweet if you think we should place the \#Chinese Communist Party at NUMBER 
1 on the Terror List" (Moonshot, 2020). - «Pетвіт, якщо вважаєте, щчо потрібно поставити комуністичну партію \#Китаю на 1 МІСЦЕ у \#спискоктерористів».

"Very true. However, we might have offended the occasional noodle nigger that visits this site if he thinks we're giving credit to the gooks for coronavirus. They're sensitive, you know" (LIGHT, 2020). - «Щира правда. Однак, ми могли образити випадкового локиинового ніггера, який сюди ходить, якщо він подумає, наче ми віддаємо честь гукам за коронавірус. Знаєш, вони ж чутливі».

Калькування здебільшого було використано для перекладу назв хвороб: “Let's not forget they gave us SARS and Bird flu too" (Twitter). - «Не забуваймо, що вони створили для нас mе ŭ SARS i пташиний гpun». "China 'willfully inflicted coronavirus upon the world" (Twitter). «Китай «цілеспрямовано наслав коронавірус на світ».

Використання комплексної трансформації, характеризувалося наявністю в них таких прийомів як заміна, перестановка, вилучення, додавання: "Thanks for gifting $d$ Deadly pandemic to $d$ world. You didnt sparedur citizens either. By the way what bout those lacs of dead bodies. What happened to them? Can anyway officially change ur country's name to Corona in place China! (7) \#ChinaLiedPeopleDied"(Twitter). - "Дякую, щчо подарували світові смертоносну пандемію. Ви не пошкодували навіть власних громадян. До речі, як щцодо сотень тисяч мертвих тіл? Що з ними сталося? -) У будь-якому разі можете перейменувати свою краӥну на Корон замість Китаю! 19)КитайЗбрехавЛюдиПомерли».

Окрему увагу слід приділити аналізу перекладу, поширених на сьогоднішній день хештегів на COVID-тематику, в яких наявна дискримінаційний контекст та обвинувачення для збереження цих характеристик у тексті перекладу, автор вдався до трансформацій поданих нижче.

Вивівши логічне значення із вихідної лексеми «fuck», перекладач використав смисловий розвиток (модуляція) та здійснив вибір варіантного відповідника, що уможливило досягнення еквівалентного перекладу: “\#FuckChina” (Moonshot, 2020). «HA **ŭKumaŭ».

Використавши трансформацію перестановки та вибору варіантного відповідника, перекладач адаптує англомовний хештег до мови цільової лінгвокультури: “\#HoldChinaAccountable” (Moonshot, 2020). - «\#КитайMaєBiдnoвicтu».

Використавши у наступному прикладі описовий переклад (експлікація), автор досягає еквівалентності у мові перекладу: “\#Chinazi” (Moonshot, 2020). - «\#Китайцінацисти».

Наступний приклад $є$ яскравою демонстрацією того, як за допомогою транскодування та калькування можна перекласти новоутворенні складені слова, що до речі $\epsilon$ також однією

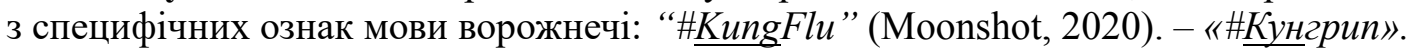

\section{5. Мова ворожнечі у телешоу та фільмах}

Кіно- та телемистецтво окрім розважальної та пізнавальної функції, характеризується висвітленням актуальних реалій певного періоду часу, а також критику наявних проблем у суспільстві. Усвідомлюючи цей факт, ми вирішили дослідити, як мова ворожнечі проявляється у кінострічках та певних телешоу, а також які вона має підгрунтя.

Для перекладу багатозначних слів, перекладачі вдавалися до трансформації вибору варіантного відповідника. Таким чином авторами наступних перекладів було підібрано перекладні лексико-семантичні варіанти багатозначних слів мови оригіналу. Вибір варіантного відповідника часто використовувався $з$ дослівним перекладом: “Where is your beautiful, merciful faggot now?” (South Park, 1999). - "Де зараз ти, прекрасний милостивий гомосек?» (South Park, 1999).

У наступному прикладі також можна помітити вдале поєднання використання дослівного перекладу та модуляції для відтворення змісту першого речення (таким чином автору вдалося коректно інтерпретувати англійське сленгове слово «backwards», що має значення «божевільний». Смисловий розвиток також став у нагоді при перекладі англійського 
«spook» (первинне значення якого «шпигун», «агент»), так перекладачу вдалося передати коректний зміст повідомлення, підібравши обсценну лексему «чорномазі», що в українській мові має різко негативне емоційне забарвлення (використано також прийом експресивізації). Що цікаво, на значенні слова «spook» заснований фільм «Заплямована репутація» (англ. The Human Stain), spook є одним із пейоративних варіантів на позначення афроамериканців в США (Multitran Dictionary). Цей приклад також характеризується використанням граматичної трансформації - об'сднання речення, а також вибором варіантного відповідника (kikes «жиди»): "It's just so beautiful. We're cleansing this country of a backwards race of chimpanzees. First the spooks. Then the kikes" (Blackkklansman, 2018). - «Все буде так гарно. Ми чистимо ию краӥну від відсталої раси шимпанзе: спочатку від чорномазих, потім від жudiв» (Blackkklansman, 2018).

У наступному висловленні $з$ фільму «Чорний куклусклівець» продемонстровано вдале поєднання лексичних та граматичних трансформацій. Наприклад за допомогою вибору варіантного відповідника перекладено insidious, tutelage, overthrow, beast agitators. Вираз Negro's...under the tutelage of high-ranking, blood-sucking Jews перекладено за допомогою описового перекладу. Складене слово blood-sucking відтворено завдяки заміні та калькулюванню (кровопивиі). 3 виразу "using an army of outside northern black beast agitators" було упущено прикметник outside (прийом вилучення). За допомогою смислового розвитку (модуляції) було відтворено значення слова determined - «мають намір». Вилучення відбулося у словосполученні «white race», так як автор передав його просто через «білі», зберігши оригінальне значення: “And the Negro's insidious tactics, under the tutelage of highranking, blood-sucking Jews, using an army of outside northern black beast agitators, determined to overthrow the God-commanded and biblically inspired rule of the white race" (Blackkklansman, 2018). - "А підступні тактики негрів, якими_опікуються кровопивиі-свреї на високих посадах, які використовують армію північних чорних чудовиськ-агітаторів, щзо мають намір повалити правління білих» (Blackkklansman, 2018).

Адаптуючи висловлювання, наведене нижче, для цільової лінгвокультури, перекладач вдався до комплексної трансформації: заміна і перестановка відбулася у виразі "they're lying, dirty monkeys, stopping". За допомогою модуляції та вилучення відтворено вираз "to gain their equality with white men": "They're lying, dirty monkeys, stopping at nothing to gain their equality with white men" (Blackkklansman, 2018). - Ці брехливі і брудні мавпи ... не зупиняться не перед чим, поки не зрівняються з білими " (Blackkklansman, 2018).

\section{6. Мова ворожнечі у Інтернет-мемах}

Окремим способом реалізації та поширення мови ворожнечі $\epsilon$ меми, що наразі $\epsilon$ надпопулярними. Мемам притаманне злісне висміювання певних людських вад та особливостей, також їх характерною ознакою $є$ іронізація чи саркастикація актуальних проблем у суспільстві. Меми - це як короткий довідник існуючих настроїв і проблем у суспільстві (як доказ - варто лишень загуглити «популярні меми сьогодення», як вам видасть швидке summary усього, що відбувається у світі). Саме тому ми вирішили включити у наше дослідження аналіз мови ворожнечі у сучасних мемах. У проаналізованих нами мемах переважала дискримінація за расовою приналежністю, антисемітизм, а також прояв нетерпимості до людей з фізичними та розумовими вадами.

За результатами проведеного кількісного аналізу, ми встановили, що при адаптації англомовних мемів для української лінгвокультури найбільше використовувався дослівний переклад. Наприклад: “Delete Israel” - THE MUCH NEEDED BUTTON” (Oboler, 2013, p.34). «Видалити Ізраӥль» - найпотрібніша кнопка» (Рис. 1). 


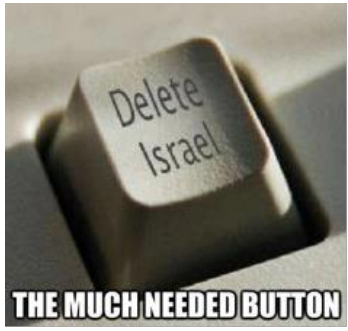

Puc. 1. Recognizing Hate Speech: Antisemitism on Facebook

“No less beautiful” (Hateful Memes Challenge, 2021). - «Не менш гарно» (Рис. 2).

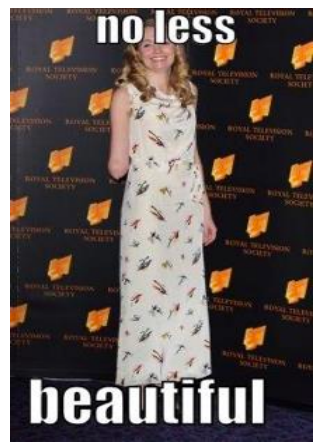

Puc. 2. Hateful Memes Dataset

На нашу думку, такий вибір перекладачів, зумовлений особливостями тесту мемів на синтаксичному рівні (зазвичай це прості речення, або просто словосполучення). Частотність використання прийому варіантного відповідника обумовлена лексичною особливістю мемів використання загальновживаних/загальновідомих англійських слів, до яких в українській мові можна підібрати лексико-семантичний відповідник.

У наступному прикладі використано дослівний переклад та додавання, 3 метою конкретизації змісту, зображеного на мемі:

“When your ex ask you for help" (Hateful Memes Challenge, 2021). - «Коли колишній хлопець просить про допомогу» (Рис. 3).

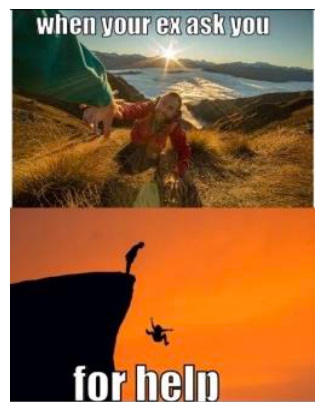

Pис. 3. Hateful Memes Dataset

У прикладі нижче також використовується дослівний переклад 3 додаванням означення (сатр - «спеціальний табір»), тим самим перекладачу вдається передати вербально ті прояви мови ворожнечі, що у цьому випадку більше передаються невербально (зображення Гітлера, як символа нацизму та винищення єврейського народу): “CAN'T CONCENTRATE? I HAVE A CAMP FOR THAT" (Oboler, 2013, p. 39). - "HE MOЖEШ СКОНЦЕНТРУВАТИСЯ? У МЕНЕ С ДЛЯ ЦЬОГО СПЕЦІАЛЬНИЙ ТАБІР».

Модуляція використовувалася як прийом контекстуальної заміни у більшості 
випадків, коли значення специфічних англійських слів та виразів, можна/необхідно було передати в перекладі словом, значення якого є логічним розвитком лексеми вихідної мови: "Starships were meant to fly. Like Jews were meant to die" (Oboler, 2013, p. 48). - «Космічні кораблі створені літати. Як євреї створені вмирати» (Рис. 4).

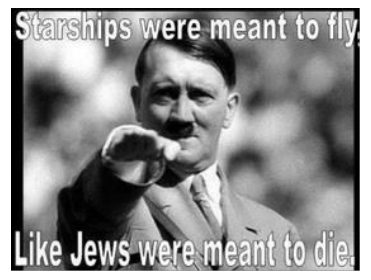

Puc. 4. Recognizing Hate Speech: Antisemitism on Facebook

У наступному прикладі модуляція використовується у поєднанні з експресивізацією для перекладу виразу «was seeing someone else» - «стріляти очима». Дієслово «to dump» відтворено за допомогою вибору варіантного відповідника, проте перекладач вирішив нейтралізувати його емоційне забарвлення («розійтися»). Також тут використано прийом додавання: "I once dumped a cross eyed chick thought she was seeing someone else" (Hateful Memes Challenge, 2021). - «Одного разу я розійшовся з косоокою дівчиною, бо здалося, щчо вона стріляла комусь іншому очима» (Рис. 5).

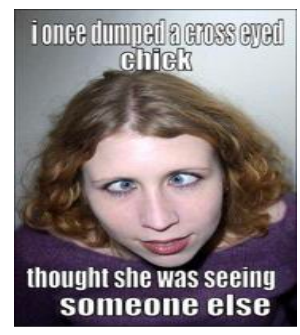

Pис. 5. Hateful Memes Dataset

Також у процесі проведення кількісного аналізу було встановлено, що при перекладі мемів, перекладачі рідше вдаються до таких трансформацій як: калькування, додавання, комплексна трансформація, вилучення, перестановка, конкретизація та нейтралізація.

Результати проведеного аналізу показали, що використання перекладацьких трансформацій може дещо відрізняється залежно від сфери вживання риторики ненависті. Так, наприклад, при перекладі hate speech щодо пандемії COVID-19 переважно використовувалися такі трансформації, як: дослівний переклад, вибір варіантного відповідника, вилучення, калькування, транскодування, смисловий розвиток; а при відтворенні «hate speech» у кіно - вибір варіантного відповідника, модуляція, дослівний переклад, вилучення, додавання та заміна. При цьому при відтворенні «hate speech»у соціальних мережах та рекламних кампаніях, переважали одні й ті ж прийоми: вибір варіантного відповідника, дослівний переклад, смисловий розвиток та комплексна трансформація. Загальні результати проведеного комплексного кількісного аналізу використання перекладацьких трансформацій при відтворенні майже 400 англомовних висловлювань, з ознаками мови ворожнечі представлені у діаграмі нижче (Рис. 6). 


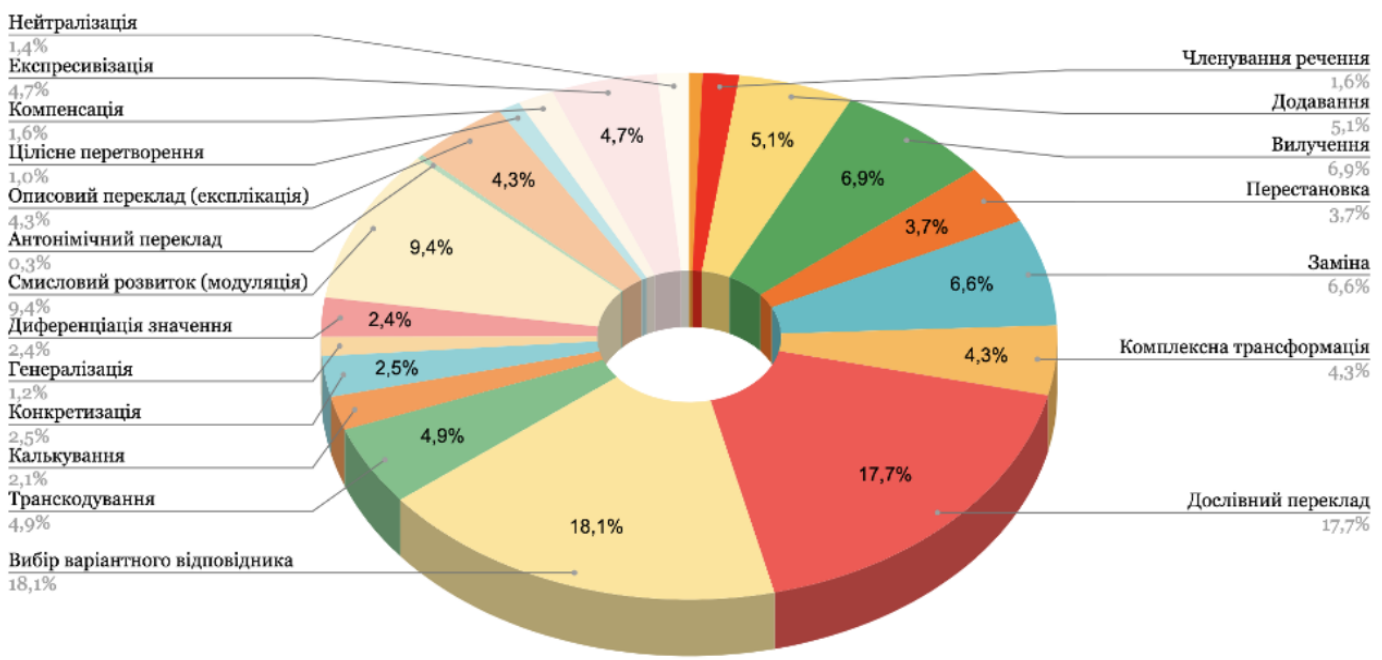

Рис. 6. Використання трансформацій при перекладі висловлювань з ознаками мови ворожнечі

\section{4. ВИСНОВКИ І НАПРЯМИ ПОДАЛЬШИХ ДОСЛІДЖЕНЬ}

У результаті проведеного дослідження було доведено актуальність такого маловивченого та небезпечного явища як мова ворожнечі. Також було доведено, що ключову роль у протидії мові ворожнечі відіграють лінгвісти, які можуть дослідити усі можливі ознаки мови ворожнечі, що уможливлює іiї потенційно швидку ідентифікацію.

У процесі аналізу прикладів, було підтверджено гіпотезу, що переклад висловлювань 3 ознаками мови ворожнечі є складним та творчим процесом, при якому перекладач стикається 3 певними складнощами. Крім професійних навичок, тобто володіння мовами та вмінням послуговуватися перекладацькими трансформаціями, перекладач має володіти екстралінгвістичними знаннями, а саме: бути обізнаним у соціокультурних особливостях лінгвокультури мови оригіналу та мови перекладу. На нашу думку, усе вищеперераховане $\epsilon$ надзвичайно важливим для, по-перше, досягнення еквівалентності та адекватності перекладу, i, по-друге, для здійснення коректної адаптації мови ворожнечі для людей 3 іншим світоглядом та менталітетом, з іншою лінгвокультурою. Варто також зазначити, що процес перекладу мови ненависті ускладнюється морально-етичними чинниками. 3 одного боку, необхідно досягти еквівалентності у перекладі, проте, з іншого боку, іноді мова ворожнечі досягає такої інтенсивності, що перекладачі використовують прийом нейтралізації. У деяких випадках автори перекладу використовують й техніку експресивізації (наприклад, коли при використанні дослівного перекладу не вдається зберегти емоційне забарвлення деяких лексем оригіналу).

Здійснено та продемонстровано результати кількісного аналізу, що здійснювався на основі 400 одиниць англомовних висловлювань 3 ознакою мови ворожнечі, а також проаналізовано перекладацькі трансформації, які використовуються при ії передачі українською мовою. За результатами кількісно аналізу було виявлено, що для досягнення адекватності та еквівалентності перекладу, перекладачі найчастіше послуговувались такими трансформаційними прийомами: дослівний переклад $(17,7 \%)$, вибір варіантного відповідника $(18,1 \%)$, модуляція $(9,4 \%)$, вилучення $(6,9 \%)$, заміна $(6,6 \%)$, додавання $(5,1 \%)$, транскодування (4,9\%), експресивізація $(4,7 \%)$, експлікація $(4,3 \%)$, комплексна трансформація (4,3\%). Найрідше при відтворенні мови ворожнечі українською мовою перекладачі вдавалися до наступний перекладацьких прийомів: перестановка $(3,7 \%)$, конкретизація $(2,5 \%)$, диференціація значення $(2,4 \%)$, калькування $(2,1 \%)$, членування речення $(1,6 \%)$, компенсація $(1,6 \%)$, нейтралізація $(1,4 \%)$, генералізація $(1,2 \%)$, цілісне перетворення (1\%), антонімічний переклад $(0,3 \%)$.

До перспективних векторів подальших наукових пошуків у дискурсі мови ворожнечі слід віднести такі аспекти: соціо-, психо-, а також когнітивний аспект (дослідження потребує вплив на людину вербальних, невербальних та паравербальних проявів прихованої агресії). 
Перспективним є дослідження hate speech у рамках прикладної лінгвістики, наприклад, 3 метою створення семантико-тематичних словників проявів «мови ворожнечі» та постійне їх оновлення, для вдосконалення існуючих фреймворків штучного інтелекту для автоматичної ідентифікації «мови ворожнечі» у текстах та зображеннях.

\section{СПИСОК ЛІТЕРАТУРИ}

Бархударов Л. С. Язык и перевод: Вопросы общей и частной теории перевода. ЛКИ, 2014. 240 с.

Комиссаров В. Н. Современное переводоведение: учебное пособие. ЭТС, 2001. 424 с.

Blackkklansman. URL : https:/www.amazon.com/Blackkklansman-John-David-Washington/dp/B07G7DBTSN

Brennan C., Feldman K. H\&M slammed for racism after showing black boy in "coolest monkey in the jungle" hoodie. URL : https://www.nydailynews.com/news/world/h-m-slammed-racism-coolest-monkey-jungle-hoodie-article1.3744160

Brown K., Healy A., Moon J. 75 Shocking vintage ads (2018). URL : https://www1.insh.world/til/

Facebook. https://www.facebook.com/

Hateful Memes Challenge. URL : https:/hatefulmemeschallenge.com/

LIGHT. Rising Levels of Hate Speech \& Online Toxicity During This Time of Crisis: report, 2020. URL : https://11ght.com/Toxicity_during_coronavirus_Report-L1ght.pdf?fbclid=IwAR12yPh-

GIi1Ur1qwwZoCuu4nP2zG5dLxs590Exli5UXYORQCWp3w_ko1MQ

Lysenko H. L., Baklan I. M., Chepurna Z. V. Grundlagen des Übersetzens: eine Brücke zwischen Theorie und Praxis (deutsch-ukrainische Richtung): Lehrbuch. Kyiv: Verlag "Politekhnika", 2019. $204 \mathrm{s.}$

Mertes A. 12 Offensive advertisements your business can learn from (2021). URL : https://www.qualitylogoproducts.com/blog/12-offensive-advertisements/

Mollas I., Chrysopoulou Z., Karlos S., Tsoumakas G. ETHOS: an Online Hate Speech Detection Dataset, 2021.16 p. URL : https://arxiv.org/abs/2006.08328

Moonshot. COVID-19: conspiracy theories, hate speech and incitements to violence on Twitter, 2020. URL : https://moonshotteam.com/covid-19-conspiracy-theories-hate-speech-twitter/

Oboler A. Recognizing Hate Speech: Antisemitism on Facebook. Online Hate Prevention Institute, 2013.63 p. https://doi.org/10.13140/2.1.2474.5762

People Can't Stop Trolling Anti-Vaxxers with Memes (2019). URL : https://www.boredpanda.com/funny-anti-vaxxmemes/?utm_source $=$ google\&utm_medium $=$ organic\&utm_campaign $=$ organic

Sharp G. Bacardi ${ }^{-}$Says, "Get an Ugly Friend to Make You Look Better!", 2009. URL : https://thesocietypages.org/socimages/2009/06/22/bacardi-says-get-an-ugly-friend-to-make-you-look-better/

South Park. South Park: Bigger, Longer \& Uncut, 1999. URL : https://www.amazon.com/South-Park-Bigger-LongerUncut/dp/B000HX6DCO

Multitran Dictionary. URL : https://www.multitran.com/

Twitter. URL :https://twitter.com/

\section{REFERENCES}

Barkhudarov, L. S. (2014). Yazik y perevod: Voprosy obshchei y chastnoy teoryy perevoda [Language and Translation: Issues of General and Particular Theory of Translation]. LKY. [in Russian]

Blackkklansman. (2018). https://www.amazon.com/Blackkklansman-John-David-Washington/dp/B07G7DBTSN

Brennan, C., \& Feldman, K. (2018). H\&M slammed for racism after showing black boy in "coolest monkey in the jungle” hoodie. https://www.nydailynews.com/news/world/h-m-slammed-racism-coolest-monkey-junglehoodie-article-1.3744160

Brown, K., Healy, A., \& Moon, J. (2018). 75 Shocking vintage ads. https://www1.insh.world/til/

Facebook. https://www.facebook.com/

Hateful Memes Challenge. (2021). Hateful Memes Dataset. https://hatefulmemeschallenge.com/

Komissarov, V. N. (2001). Sovremennoie perevodovedeniie: uchebnoie posobiie [Modern Translation Studies: Textbook]. YETS. [in Russian]

LIGHT. (2020). Rising Levels of Hate Speech \& Online Toxicity During This Time of Crisis: report. https://11ght.com/Toxicity_during_coronavirus_Report-L1ght.pdf?fbclid=IwAR12yPh-

GIi1Ur1qwwZoCuu4nP2zG5dLxs590Exli5UXYORQCWp3w_ko1MQ

Lysenko, H. L., Baklan, I. M., \& Chepurna, Z. V. (2019). Grundlagen des Übersetzens: eine Brücke zwischen Theorie und Praxis (deutsch-ukrainische Richtung): Lehrbuch. Kyiv: Verlag «Politekhnika». [in German]

Mertes, A. (2021). 12 Offensive advertisements your business can learn from. https://www.qualitylogoproducts.com/blog/12-offensive-advertisements/

Mollas, I., Chrysopoulou, Z., Karlos, S., \& Tsoumakas, G. (2021). ETHOS: an Online Hate Speech Detection Dataset. https://arxiv.org/abs/2006.08328

Moonshot. (2020). COVID-19: conspiracy theories, hate speech and incitements to violence on Twitter. https://moonshotteam.com/covid-19-conspiracy-theories-hate-speech-twitter/

Multitran Dictionary. https://www.multitran.com/ 
Oboler A. (2013). Recognizing Hate Speech: Antisemitism on Facebook. Online Hate Prevention Institute. https://doi.org/10.13140/2.1.2474.5762

People Can't Stop Trolling Anti-Vaxxers with Memes. (2019). https://www.boredpanda.com/funny-anti-vaxxmemes/?utm_source=google\&utm_medium=organic\&utm_campaign=organic

Sharp, G. (2009). Bacardi Says, "Get an Ugly Friend to Make You Look Better!". https://thesocietypages.org/socimages/2009/06/22/bacardi-says-get-an-ugly-friend-to-make-you-look-better/

South Park. (1999). South Park: Bigger, Longer \& Uncut. https://www.amazon.com/South-Park-Bigger-LongerUncut/dp/B000HX6DCO

Twitter. https://twitter.com/

Valentyna Marchenko, Olena Matiushenko. Ways of translating hate speech utterances from English into Ukrainian. The article is devoted to the study of the peculiarities of translation of hate speech by means of the Ukrainian language. Among the research methods, the structural method occupies a prominent place, thanks to which the language of hostility as a system is considered, with its characteristic components: verbal and nonverbal means and forms of implementation in language. The use of a comparative method allows us to establish similarities, differences and specifics of the English-language means of expression of hate speech through systematic comparison with the Ukrainian language. The dominant method of the presented research is the quantitative analysis of the texts of the original and the translation, which is used to determine the most frequent ways of reproducing the means of hate speech in translation. Particular attention is paid to the identification of the most frequent methods of translation of hate speech, which allows the preservation of its linguo pragmatic and socio-cultural features. The linguo pragmatic and sociocultural aspects are also considered. The article presents the results of the quantitative analysis of the use of translation transformations in the reproduction of hate speech for foreign linguaculture. The presented study demonstrated the results of a quantitative analysis based on nearly 400 English-language utterances, which were recorded in different uses and in different forms of manifestation. The most prominent examples were analyzed in detail, justifying one or another choice of mode of translation. The analysis of translation was presented according to the following structure: hate speech in modern social networks; manifestations of hate speech recorded in modern advertising campaigns and vintage advertisements; manifestations of hate speech caused by COVID-19; hate speech recorded in television shows, TV shows, and movies; manifestations of hate speech in Internet memes The phenomenon of "hate speech" is also seen as an actual interdisciplinary phenomenon, which requires thorough scientific and linguistic research, to prevent its dangerous consequences.

Keywords: hate speech; hate rhetoric; hate speech; verbal and non-verbal means of hate speech; translation aspect; sociocultural aspect. 